和歌以県立医科大学，外科教空（主任：浜光治教授）と

第 2 解剖影教室（主任：高木耕三教授).

Dept. of Surgery (Director; Prof. M. HAMA) and

II. Dept. of Anat. (Director; Prof. K. TAKAGI), Wakayama Med. College.

\title{
無蛋白食飼育ラッテの朋紃胞糖原とその \\ 意義に就て。 \\ On Glycogen in the Liver Cells of Rat after Feeding them with Non-protein Food and its Significance.
}

\section{高橋末 広 Suehiro TAKAHA.SHI.}

〔昭和 29 年 6 月 17 日原稿受付.〕

肝細胞構造は給食後間もなく機能的動態を示し, 時間の経過と共に胞体 中飞糖原, 脂質等所謂貯蔵物質が増量し，一定時間を経ると次第飞消失す ることは周知の事実である，就中糖原の蓄積は肝細胞機能として最も大な るものの一つで, 肝細胞機能の重要なる標準となり得ることは今更喋々す るまでもない，著者は襄飞無蛋白食飼育ラッテの十二指腸上皮細胞が明か 飞機能低下乃至退行変性への過程を示す事を細胞及び核の変形 Plastosome の形態恋化並飞 Phosphatase 反応の減弱等より形態学的飞証明した（日 組録， 5 巻， 1 号，昭28). 而して之が単に十二指腸に限らず小腸全般飞 共通であることを其後の研呪と於て識り，愈々確信をるつに至った。ここ に於て無蛋白食飼育ラッテに給食した時, その肝細胞糖原が如何なる消長 を示すか, 而して若しその消長に異変ありとすれば, それは肝細胞機能に 由来するか，それとも小腸と於ける吸收能力によるかを分折することは， 形態学的に示された小腸上皮細胞機能を裏付ける上飞重要であり，且興味 があると思われる。著者が本研究を企図した所以はこことある.

\section{I. 実験材料と研究方法。}

実験動物は体重 $100-120 \mathrm{~g}$ の健康成熟雄ラッテで，一匹宛金網製の籠 そ入れ，実験前 5 日間人工基礎食の時間的給食飞炰らせた。爾後之等を 3 群飞分け，第 1 群はそのま〉人工基礎食で飼育して対照とし，第 2 群には 無蛋白食を投与して夫々 $10 ， 20 ， 30$ 及び 40 日間飼育し，最終給食後 24 時間 離食せしめて再び同一食餌を給食，30分後飞残余の慨を取り去り，それよ り $1 ， 3 ， 6$ 及び 24 時間後飞取材した。 又第 3 群は無蛋白食とて 30 日間飼育

\footnotetext{
* 本論交の要旨は第58回日本解剖学会総会に於て発表した。
} 


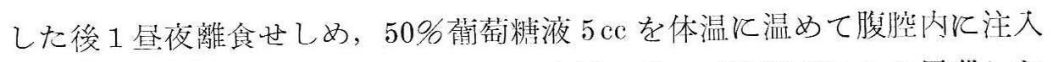
し，1時間及び3時間後に取材した。取材に当っては断暊により屠殺した 後肺より所岀小片を摘出し, Rossman 氏液にて24時間固定, 所定の操作を 経てパラフィン包理を行い，10 ルの切牌を作轅，4醌酸鉙-Schiff 法（清 水-熊本，1952）飞よる多糖類染色及び Best 氏カルミン染色を施した.

\section{1. 自家所見.}

\section{A. 第 1 群 (対照. 人工基礎食飼育).}

1. 空腹時（給食後 24 时間）。

朋細胞は殆しど一様と小形で，規則正しく配列し，糖原を全く有しない。

2. 給食後 1 時間.

細胞は軽菖に膨大している，小葉中心部では少数の料原顆粒を有する細 胞と之る全く有しない細胞が混在している，小㳭中間部，周辺部の細胞飞 は前者よりも稍々浱染した多数の糖原顆䊉を認める。

\section{3. 給食後 3 時間 (四 1 ).}

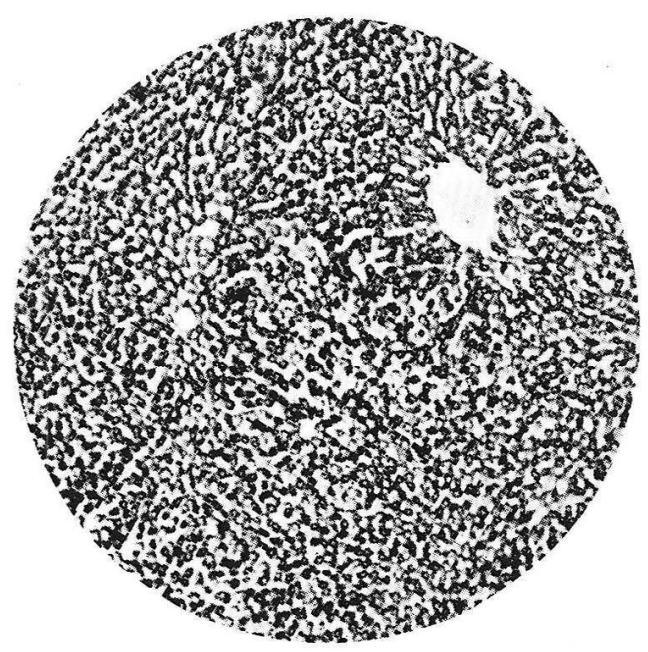

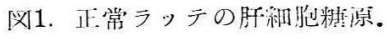

Fig. 1. Glycogen in the liver cells of a normal rat.
朋細肘は叮成り膨大し， 細胞索は僅かに乱れてい る. 精原は小葉各部の別 なく一椂に認められ，浱 染した中等大顆精として 胞体中に充満している. 然し小葉中間部, 周辺部 そあっては糖原充渾の細 胞飞混じ, 糖原を全く有 しないか或は極く僅かに 有するのみで, 此較的大 きい突胞で充ちた細胞が 散見せられる。

4. 給食後 6 時間.

細胞の形態は給食後 3 持間と大差がない。粺原

は概ね総ての紐胞に现われその多くが浠染したり等大顆粃として認めら

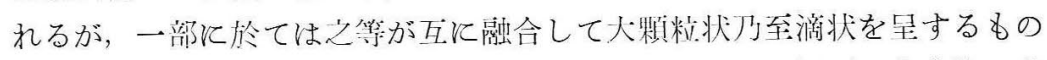

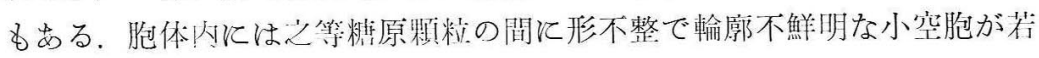
干認められる。 


\section{B. 第 2 群（無蛋白食飼育）。}

1. 10 日間飼育（汹2, 給食後 3 時間）.

朋細胞精原は一般飞第 1 群 (対照) 飞比べて軽 度の增量を示すことが注 目せられる。即ち給食後 1 洔澗で既に可成り多量 が認められ，24時間後代 於て子小葉周辺部細胞中 には尚淡染せる小顆精と して少量涊められる。然 乙糖原消長の時間的経過 壮第 1 群と変りなく, 給 食後次第比增量し 6 时闰 後飞て最多多量を示与。

2. 20 日開飼育（汹 3 , 給食後 3 時間).

本例飞於ける粕原消辰

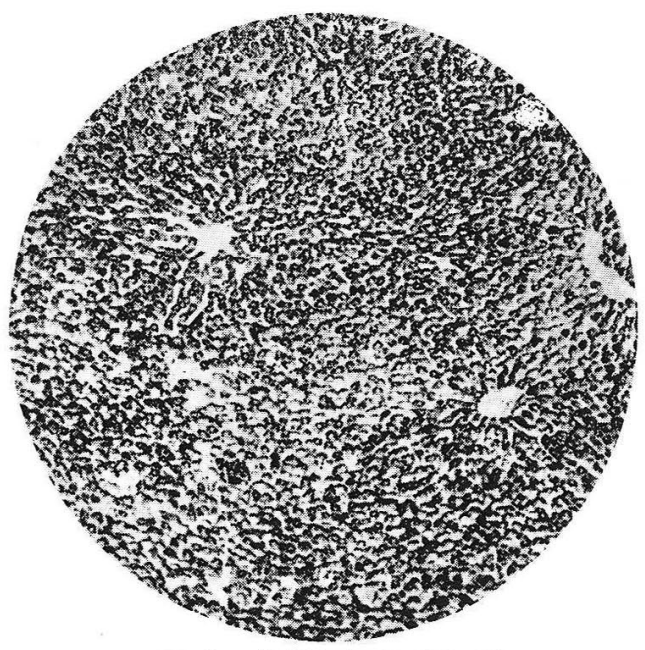

四 2. 然蛋白食 10 日鸰省例。

Fig. 2. Glycogen in the liver cells after fed with non-protein food for 10 days.

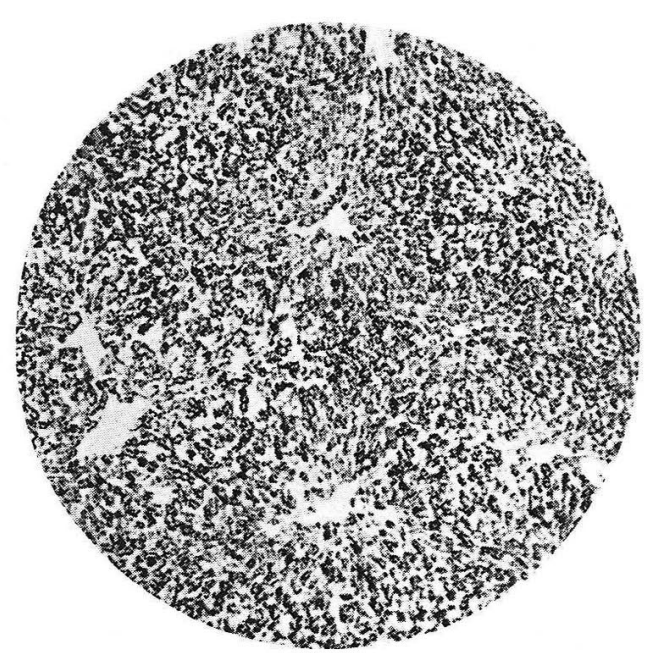

四 3，重蛋白食20日飼曹例。

Fig. 3. Glycogen in the liver cells after fed with non-protein food for 20 days.
注10日間飼育例とは叮成 り趣を異にし，明かに低 調となる。即ら給食後 1 时間で糖原は殆んど現わ れず， 3 时間後にて始め て巾等星となり，6時间 後には多星を示すが，24 時间後には全く認めない。 しかし最も多量を示す 6 時間飞於ても, 対照及び 10日例のそれに比較する と明か飞少い。

3. 30 日間飼育（汹 4 , 給食後 3 時間)。

肝細胞は姜縮し核は胞 体の大いさに比して可成 


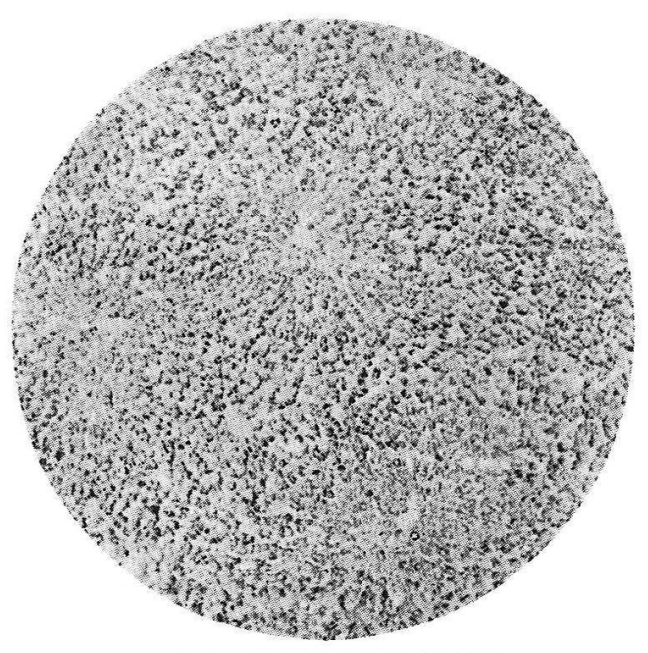

汹4. 無蛋白食30日飼尚例.

Fig. 4. Glycogen in the liver cells after fed with non-protein food for 30 days.
り大にすぎる観がある。

朋細胞の配列は不規則と なり細胞索は多少乱れる。 又小葉周辺部の細胞内、 脂肪空胞が多数に現われ る、之等は30日飼育飞到 って始めて認められる著 変と言うことが出来る。 他方朋細胞糖原の消長は 20 日間飼育例上り 子吏飞 低調で且不規則となり， 給食後 1 時間飞て少呈出 現するが， 6 時閏後に到 るも增加せず，又24時間 後になっても全く消失す ることはない。

4. 40 日間飼公.

$30 \mathrm{H}$ 間飼育例と大差ないが，多数の脂肪空胞を有する細胞が一段と增数 している点が特異的である。

\section{C. 第了群（無蛋白食 30日飼育後葡萄糖 液腹腔內注入).}

1. 注入後 1 時間.

肝細胞队び紐胞索には 第 2 群の30 E間飼育例と 大差はないが，胞体内に 円形空胞（脂肧）を比輷 的多数証める点のみが異 る、朋縕胞糖原は中等大 の比較的浱染した颗䊉と して小葉全般に问成り多 数認められる。忌は第さ 群30日飼育例のいずれの 時期に見たよりる遙かに

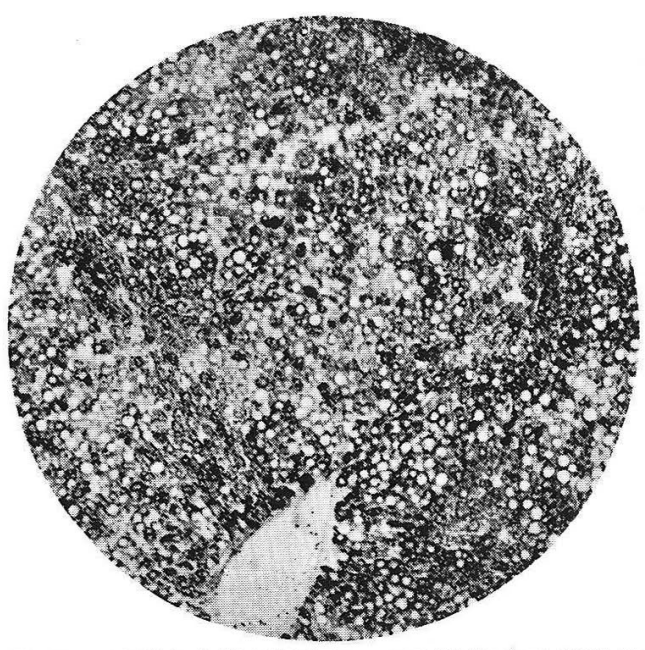

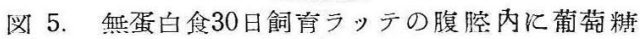
预を拄入した例。

Fig. 5. Glycogen in the liver cells after infusing glucose solution into the peritoneal cavity of a rat, fed with non-protein food for 30 days. 
多い.

2. 注入後 3 時間 (図 5 ).

肝細胞の構造，形態等は前者と略々同様である。糖原は前者に比して僅 かに減少しているが，尚可成り多量を示し，第 る群30日飼育例飞比べると 明かに多いと言える。

\section{小 括.}

以上の所見を要約すると，

1. 正常ラッテに於ては肝細胞糖原は給食後時間の経過と共に増量し, 6 時間後飞最も多く，爾後減少し，24時間後には全く消失している. 又糖 原は給食後 1 時間飞於ては小葉中心部よりも周辺部の組胞に多いが，その 後增量するに従い部位的に差異を認めない. 従って糖原の出現は小葉周辺 部に始まるものと思われる。

2. 肝細胞糖原は淡染小顆粒より濃染大顆粒乃至滴状に至る各㮔の段階 を示している。

3. 無蛋白食にて飼育与ると肝細胞は一般に萎縮し，胞体と核の大いさ のつり合いが破れ，又細胞の配列が不規則となり，細胞索は乱れる．他面 細胞内には脂肪空胞が多数現れる.

4. 無蛋白食飼育日数の増加と共飞, 給食後肝細胞飞出現する糖原は減 少し，且その消長の時間的経過も不規則になる。之等は飼育 30 日飞到って 最も著しく，40日飞到っても大差ない.

5. 無蛋白食飞て 30 日間飼育したラッテの腹腔内に $50 \%$ 葡萄糖液を注入 すると，肝細胞糖原は人工基礎食飼育ラッテに注入した場合よりも少いが， 実験第 2 群の給食した場合よりも遙かに多量証明出来る.

と言うことになり，之等所見のうち肝細胞糖原の消長は次表の如く現わ される。

\section{III. 考察.}

正常時に於ける肝細胞糖原は給食後時間の経過と共に增量し，略々 6 時 間後を頂点として爾後減少し，給食 24 時間後とは全く消失することは，高 木教授ととの門下及び内外諸家による業績により実証され，今や何人も疑 わない所である，著者の今回の契験（第 1 群）飞於ても諸家の成績と同様 飞, 給食後 6 時間飞て最高となり, 以後漸次減少して 24 時間後には全く消 失している，然し之等は各栄養素を含む完全食にて飼育した場合の成績で ある，然らば今 1 つの栄養素を欠除したものにて飼育した場合には，如何 


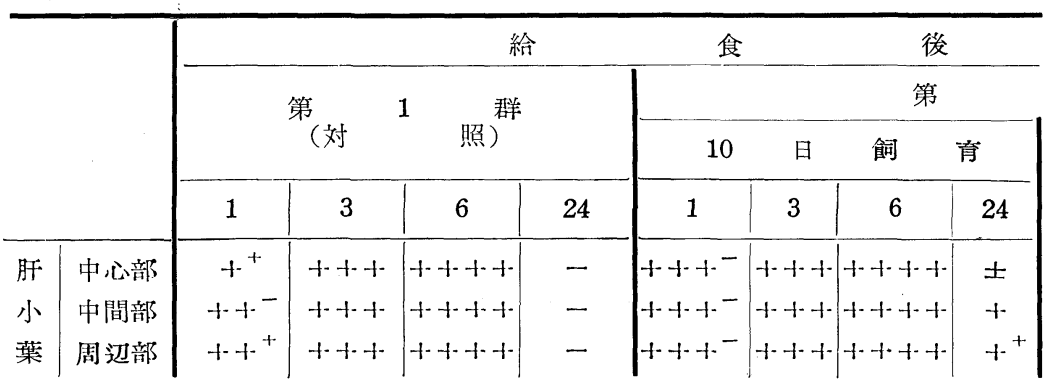

なる変化が起るであろらかと言う問題は非常と興味がある。

著者はとの 1 つして今回無蛋白食飼育を試みた（第 \&群）．との結果 無蛋白食飼育が30日飞及ぶと，給食後肝細胞飞現れる糖原は真に少量とな り，6時間後に於ても增加せず，又24時間後に於て全く消失することもな いことを知った，之等は飼育が更に40日に至っても大差なく, 従って無蛋 白食飼育による影響は30日にて概ね出揃ったものと考兄られる。

抑々蛋白質の欠乏があらゆる細胞機能を障害するであるうことは容易飞 想像される。殊飞肝細胞機能に関しては, Lightbodyと Kleinman, Kaplansky, Miller, Whipple, 平出等飞より酥素学的に証明せられ, 又最近 では浜教授，佐藤が形態学的にも証明している，従って著者の得た肝細胞 糖原消長の低下（第２群）は，肝細胞機能の低下に起因したことは否めな いであるう。けれども蛋白質欠乏は単に肝細胞にのみ影響を及ぼすもので あろらか，著者は暴の研究に於て 30 日飞亘る蛋白質欠乏が，小腸上皮細胞 の機能低下乃至退行変性を招来することを証明した．此所飞於て考劣るべ きことは，給食後肝細胞飞現われる糖原は，経腸的飞肝へ到った筈である と言うことである。従って肝細胞に現われる糖原が少量であると言う事実 を以て直ちに之が肝細胞機能低下によるとのみ考えることは，無蛋白食飼 育実験飞於ては一方的でありすぎ，仮令肝細胞機能が正常でる小腸上皮細 胞の吸收機能が障害せられているならば，肝細胞に出現する糖原その他は 少量であり得ると言う可能性を忘れてはならないと思う。此所飞於て著者 はラッテを無蛋白食とて30日間飼育した後, 空腹時に葡萄糖溶液を腹腔内 へ注入した。 その結果 1 時間後には多量の糖原が肝細胞に証明され， 3 時 間後にも尚可成り多量を見た（第3 群），之を無蛋白食飼育ラッテに給食 した後の肝細胞糖原と比較すると, 遙かに多量である。従って肝細胞とし ては，機能が低下したとは言光，尚可成りの糖原生成機能を保有している ものと見做して差支觉ないと思う。

従って無蛋白食飼育によって，給食後肝細胞に現われる糖原が少量とな 


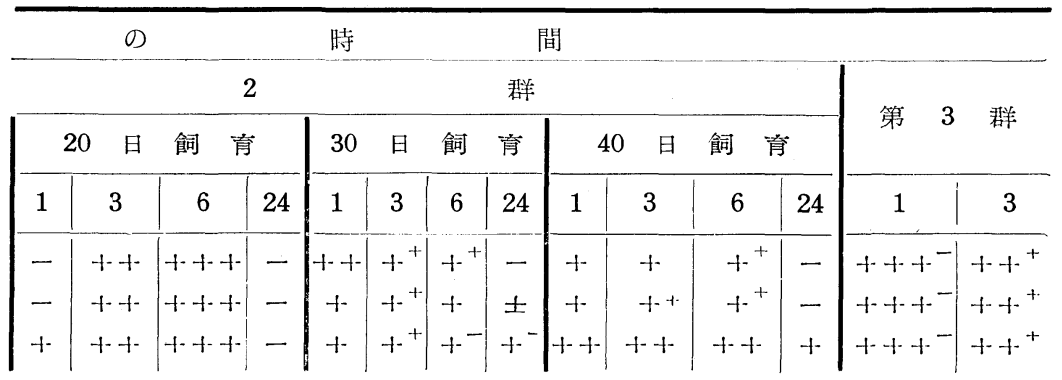

ることは，肝細胞自体の機能低下によることは否めないが，小腸上皮細胞 の機能障害が更と大なる原因となっていることを認めなければなるまい。

\section{IV. 結語.}

無蚠白食でラッテを飼育すると30日飞至り肝細胞糖原は，給食後と雖も 著明な增加を示さなくなる，従って之のみをもってしては蛋白質欠之によ って肚細胞機能が低下したものと考兄られる，処が著者は無蛋白食飼育飞 よって小腸上皮細胞も亦明かと機能低下乃至退行変性の像を示与ととを显 の研究で明かてしたので，無蛋白食にて30日間飼育したラッテと葡萄楉液 の腹坨内注入を試みたところ，肝細胞には可成り多量の糖原が出現するの を認めた。以上の成績から，上記の肝細胞糖原消長の低下怯，肝細怉自体の 機能低下に原因与ることは勿論であるうが，小腸上皮の機能低下が更に大 きな因子となっているととと信ずる。

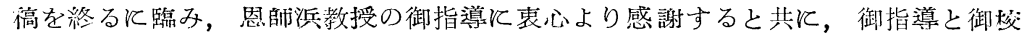
閲を賜わった解剖学教室高木教授出に藤江助教授に対し満腔の謝意を捧げる.

\section{Author's Abstract.}

In the liver cells of rats fed with non-protein food for 30 days, glycogen did not increase much even immediately after feeding. Solely from this result it would be considered that a hypofunction of the liver cells was caused by the lack of protein in the cells. But in a previous pager it was shown that the epithel of the rat's duodenum, when treated in the same way, fell into a hypofunction or a atrophic degeneration. Therefore the author infused glucose solution into the peritoneal cavity of rats, which were fed with non-protein food for 30 days and found that a large amount of glycogen appeared in the liver cells. Consequently the decrease of glycogen in the liver cells was caused not only by the hypofunction of liver cells, but also by the hypofunction or by an absorptive disturbance of the small intestine. 


\section{文献.}

浜光治：外科領域に於ける蛋白代謝に就て. 第50回日本外科学会総会. 昭 25.

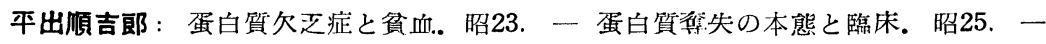

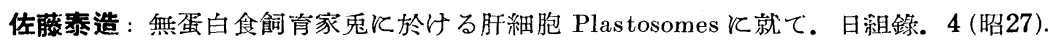
- Shimizu, N. a. T. Kumamoto: A lead-tetra-acetate-Schiff method for polysaccharides in tissue sections. Stain Technol. 27 (1952). 一高橋末広: 食餌性低

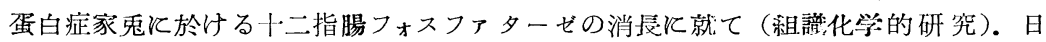
租錄。3 (昭27). 一 無蛋白食鶬育ラッテに於ける十二指腸上皮細胞飞就て. 日組錄. 5 (昭28). 一 安田光酸: 肝臟糖原質と給食との関係飞就て. 解剖誌。 23 (昭23). 